\title{
I.UMIJUNC
}

\section{SINTASAN DAN VIABILITAS BIO-KAPSUL PROBIOTIK Lb paracasei ssp paracasei MI3 HASIL EKSTRUSI DENGAN KARAGENAN-SKIM}

\author{
Mutia Elida ${ }^{1}$, Gusmalini ${ }^{1}$,dan Iza Ayu Saufani ${ }^{2}$ \\ ${ }^{1}$ Politeknik Pertanian Negeri Payakumbuh \\ ${ }^{2}$ Universitas M. Natsir Bukittinggi \\ Korespondensi:elida mutia@yahoo.com
}

$\begin{array}{ll}\text { Diterima } & : 27 \text { Agustus } 2020 \\ \text { Disetujui } & : 29 \text { Agustus } 2020 \\ \text { Diterbitkan } & : 31 \text { Agustus } 2020\end{array}$

\begin{abstract}
ABSTRAK
Pemanfaatan produk probiotik sebagai produk kesehatan dan terapeutik semakin banyak diminati, tetapi yang menjadi masalah adalah terjadinya penurunan viabilitas sel probiotik selama proses pengolahan dan selama berada dalam saluran pencernaan. Metoda ekstrusi adalah salah satu metoda enkapsulasi untuk dapat melindungi sel probiotik dari kondisi lingkungan yang tidak menguntungkan. Enkapsulasi probiotik Lb paracasei ssp paracasei Ml3 menggunakan penyalut karagenan-susu skim bertujuan untuk melihat rendemen, sintasan probiotik atau ketahanan sel serta viabilitas setelah enkapsulasi. Penelitian dilakukan dengan tiga perbandingan yaitu $1: 1$; $2: 1$; dan $3: 1$, masing-masing perlakuan diulang 3 kali. Hasil penelitian menunjukkan bio-kapsul dengan perbandingan bahan penyalut $1: 1$ dan 2:1 menunjukkan tidak ada perbedaan yang nyata antara ke dua perlakuan baik dari segi viabilitas dan sintasan probiotik. Perbandingan bahan pernyalut 1:1 memberikan rendemen tertinggi $84.6 \%$, perbandingan bahan penyalut 2:1 dihasilkan rendemen $82.73 \%$ dan viabilitas tertinggi $1,97 \times 10^{9} \mathrm{CFU} / \mathrm{g}$ dan mengalami penurunan viabilitas sebesar $0,72 \log$ CFU/g. Sintasan sel probiotik perbandingan bahan penyalut 2:1 adalah 93.3\% dengan penurunan 0,66 Log CFU/gr lebih rendah jika dibandingkan perlakuan 3:1 .
\end{abstract}

Kata Kunci: bio-kapsul, probiotik

\section{ABSTRACT}

Utilized of probiotic products as a health and therapeutic product is increasingly in demand, but the problem is the occurrence of decreased probiotic cell viability during the processing and during the gastrointestinal tract. Extrusion method is one of the encapsulation methods to be able to protect probiotic cells from unfavorable environmental conditions. The probiotic encapsulation of the Lb paracasei ssp paracasei Ml3 used the coating of the Caragenan - skim milk aims to see the yield, the survival rate of probiotics or cell resistance as well as viability after encapsulation. The research was conducted with three comparisons of 1:1; 2:1; and 3:1, each treatment was repeated 3 times. The results showed a bio-capsule with a comparison of the starting material 1:1 and 2:1 showed no noticeable difference between the two treatment both in terms of viability and the survival rate of probiotics. The comparison of 1:1 was obtained the highest yield of $84.6 \%$, and comparison of 2:1 was $82.73 \%$ and the highest viability of $1.97 \times 10^{9} \mathrm{CFU/G}$ and suffereda reduction in viability of 


\section{I.UMBUNG}

$0.72 \mathrm{Log} C F U / G$. The survival rate of probiotics comparison of $2: 1$ of $93.3 \%$ with a decrease of 0.66 Log CFU/G lower compared to the 3:1 treatment.

\section{Keywords: bio-capsules, probiotics}

\section{PENDAHULUAN}

Produk probiotik banyak diminati karena memberikan manfaat untuk kesehatan baik untuk preventif maupun untuk terapeutik. Badan Pengawasan Obat dan Makanan, Amerika Serikat merekomendasikan jumlah minimum bakteri probiotik pada produk yaitu sebesar $10^{6} \mathrm{CFU} / \mathrm{mL}$ (Bhadoria dan Mahapatra, 2011), sedangkan menurut Krasaekoopt, Bhandari, Deeth (2003), efek kesehatan probiotik akan diperoleh bila mengkonsumsi probiotik dengan jumlah $10^{6-10^{7}}$ koloni/gr. Jumlah probiotik diharapkan stabil selama penyimpanan dan pengolahan produk agar tetap bermanfaat saat dikonsumsi. Untuk itu sintasan probiotik atau kebertahanan hidup menjadi sangat penting karena memberikan efek yang menguntungkan bagi kesehatan manusia.

Sintasan hidup probiotik ini masih rendah dalam produk pangan dan di saluran pencernaan, dimana kemampuan bertahan hidup sel probiotik selama proses pengolahan dan produksi dapat berkurang secara drastis akibat perlakuan panas atau pendinginan selama pengolahan, sehingga akan mengurangi efeknya terhadap kesehatan. Teknologi enkapsulasi dapat menstabilkan dan meminimalkan pengaruh negative dari pengolahan terhadap sel probiotik. Bakteri probiotik dapat dilindungi menggunakan bahan pelindung atau penyalut menggunakan metoda enkapsulasi.

Enkapsulasi adalah suatu proses pembungkusan (coating) bakteri membentuk inner matriks seperti kapsul yang melindungi bahan inti dengan menggunakan bahan enkapsulasi (Wu, Roe, Gimino, Seriburi, Martin dan Knapp, 2000). Menurut Krasaekoopt, Bhandari, dan Deeth (2003), enkapsulasi dapat dilakukan dengan teknik ekstrusi, dengan menambahkan mikroorganisme probiotik ke dalam larutan pelindung. Metoda ekstrusi menggunakan syringe merupakan teknologi sederhana dan murah serta tidak ada kerusakan pada sel probiotik, viabilitas tetap tinggi, tidak melibatkan pelarut yang merusak sel mikroorganisme, dan dapat dilakukan pada kondisi anaerob dan aerob (Solanki dan Himansu, 2013).

Bahan pelindung atau pengkapsul yang umum digunakan adalah berbagai jenis polisakarida dan protein seperti pati, alginat, gum arab, gelatin, karagenan, kedelai. whey, dan kasein (Desmond, Stanton, Collins and Ross. 2002), tepung terigu dan pollard 


\section{I.UMBUNNG}

(Widodo dan Wahyuni, 2003). Karagenan merupakan golongan polisakarida dan banyak digunakan sebagai stabilisator (pengatur keseimbangan), thickener (bahan pengentalan), pembentuk gel, pengemulsi. Dalam penelitian ini karagenan dipilih sebagai bahan pengkapsul berdasarkan hasil penelitian terdahulu Elida, Izza dan Gusmalini (2018), bahwa, kosentrasi karagenan $3 \%$ memberikan viabilitas tertinggi mencapai $10^{10} \mathrm{CFU} / \mathrm{g}$ pada bio-kapsul hasil ekstrusi. Susu skim ditambahan sebagai sumber protein selama sel berada dalam tahap im-mobil, sehingga viabilitas tetap terjaga.

Permasalahan yang timbul adalah penetapan kosentrasi penggunaan karagenan dan susu skim sebagai bahan pengkapsul untuk mendapatkan sinatasan dan viabilitas yang tinggi terhadap sel probiotik, sehingga sel tidak terpengaruh pada perlakuan fisik selama proses aplikasi pada bahan pangan. Penelitian ini bertujuan untuk untuk mengetahui sintasan dan viabilitas sel setelah dilakukan enkapsulasi dengan metoda ekstrusi.

\section{METODOLOGI PENELITIAN}

\section{Bahan dan Alat}

Bahan yang digunakan dalam penelitian ini adalah kultur probiotik Lb paracasei ssp paracasei M13, media MRS Broth (Merck), MRS Agar (Merck), Karagenan (Bratacahem), susu skim (Sunlac), $\mathrm{KCL}, \mathrm{NaCl}, \mathrm{HCl}$, Alkohol 90\%, Spiritus, dan Aquades.

Alat yang digunakan adalah laminar flow, hot plate, autoclave, oven, inkubator, mikropipet, syringe, timbangan analitik, vortek mikser, mikrosentrifuse, coloni counter, dan alat-alat gelas.

\section{Rancangan Percobaan}

Penelitian ini menggunakan Rancangan Acak Lengkap (RAL) dengan tiga perbandingan bahan penyalut karagenan-skim $1: 1 ; 2: 1$; dan $3: 1$, setiap perlakuan diulang sebanyak tiga kali. Variabel yang diamati adalah rendemen, sintasan sel probiotik dan viabilitas bio-kapsul setelah ekstrusi.

\section{Pembuatan Bio-kapsul}

Pembuatan bio-kapsul mengacu pada metode Le-Tien, Millette , Mateescu, dan Lacrox (2004) dan Rokka dan Rantamaki (2010) yang dimodifikasi. Kultur bakteri $L b$ paracasei ssp paracasei M13 sebanyak $10 \%$ disegarkan, kemudian disentrifus dengan kecepatan 4500 rpm selama 15 menit. Selanjutnya dicuci dengan air steril dan disentrifus kembali kecepatan 3000 rpm selama 10 menit, pellet yag dihasilkan dilarutkan dengan 


\section{I.UMIBUNG}

aquades steril hingga kosentrasi 10\%. Disiapkan karagenan 3\% steril, dan larutan skim pasteurisasi sesuai perbandingan pada perlakuan . Ke dalam suspensi ditambahkan larutan pellet yang berisi suspensi bakteri dengan perbandingan 4:1. Campuran dimasukkan ke dalam syringe diteteskan ke dalam larutan KCL 3\% steril dan dibiarkan selama 120 menit pada refrigerator. Bio-kapsul kemudian dicuci menggunakan larutan garam fisiologis sebanyak dua kali dengan selang waktu pencucian 15 menit.

\section{Rendemen Bio-kapsul}

Timbang seluruh bio-kapsul yang dihasilkan dibagi dengan jumlah suspensi campuran bahan pengkapsul dengan suspensi pellet dikali dengan $100 \%$.

\section{Sintasan Probiotik (Gebara et al., 2013)}

Sintasan probiotik ditentukan dengan menghitung jumlah sel sebelum dan setelah proses ekstrusi. Bio-kapsul sebanyak 1 gr didisintegrasikan ke dalam $9 \mathrm{ml}$ buffer pospat dan dihomogenkan menggunakan vortex selama 5 menit. Selanjutnya probiotik yang sudah keluar dari bio-kapsul dihitung menggunakan metoda TPC dan dinyatakan sebagai rendemen enkapsulasi ekstrusi (REE) yaitu jumlah sel yang mampu bertahan hidup selama proses mikroenkapsulasi dan selama berada dalam mikrokapsul yang dihitung dengan rumus (Zanjani et al., 2014).

$$
\operatorname{REE}(\%)=(\mathrm{N} / \mathrm{No}) \times 100
$$

Keterangan :

$\mathrm{N}=$ Jumlah sel probiotik dalam log CFU/g mikrokapsul

No = Jumlah sel hidup dalam log CFU/ml kultur

\section{Viabilitas Bio-kapsul}

Perhitungan jumlah sel dalam bio-kapsul dihitung mengacu pada metode (Le-Tien et al, 2004) dan (Ivanovska et al, 2012) yang dimodifkasi. Bio-kapsul diambil sebanyak 0,1 gr dan ditambahkan 9,9 ml larutan pengencer steril sehingga diperoleh pengenceran $10^{2}$, hancurkan divortek kemudian didiamkan satu jam. Selanjutnya pengenceran sampai $10^{-7}$, hitung jumlah bakteri dengan metoda TPC (Aneja, 2003). 


\section{I.UMIIUNC}

\section{HASIL DAN PEMBAHASAN}

\section{Rendemen Bio-kapsul}

Rendemen bio-kapsul dari tiga perbandingan bahan penyalut karagenan-skim seperti yang terlihat pada Tabel 1 .

Tabel 1. Rendemen bio-kapsul dari tiga perbandingan bahan penyalut karagenan-skim

\begin{tabular}{ll}
\hline Perbandingan Penyalut karagenan-skim & Rendemen $(\%)$ \\
\hline $1: 1$ & $79.83^{\mathrm{a}}$ \\
\hline $2: 1$ & $82.73^{\mathrm{b}}$ \\
\hline $3: 1$ & $84.46^{\mathrm{c}}$
\end{tabular}

Keterangan: rata-rata perlakuan yang diikuti oleh huruf kecil yang berbeda menunjukkan adanya perbedaan yang nyata pada tingkat kepercayaan $5 \%$

Rendemen tertinggi diperoleh pada perbandingan bahan penyalut karagenan-skim 3:1 yaitu $84.46 \%$. Semakin tinggi perbandingan maka semakin berat campuran suspensi maka semakin cepat jatuhnya tetesan pada bahan pengeras $\mathrm{KCl}$ dan ukuran semakin seragam. Hal ini disebabkan oleh berat molekul karagenan yang lebih besar jika dibandingkan dengan bahan penyalut lain seperti alginat, sehingga proses ekstrusi berjalan dengan sempurna dan lebih efisien dan suspensi campuran yang hilang lebih sedikit. Rendemen pada perbandingan 1:1 lebih rendah karena campuran lebih encer, proses ekstrusi kurang efisien, dimana bio-kapsul mengembang dan sedikit hancur pada permukaan $\mathrm{KCl}$.

Menurut Yunita (2011), berat molekul bahan penyalut juga berpengaruh dimana berat molekul karagenan lebih tinggi dari alginat yaitu 400-500 KDa. Hasil penelitian Muhardian, Dewi, Yulaini, dan Sri (2017), ekstrusi menggunakan karagenan sebagai penyalut yang dicampur dengan prebiotik ampas tahu dihasilkan rendemen sebesar $37.40 \%$.

\section{Sintasan Probiotik}

Sintasan probiotik adalah kemampuan matrik karagenan untuk memerangkap sel probiotik setelah ekstrusi, hasil seperti pada Gambar 1 


\section{I.UMIBUNG}

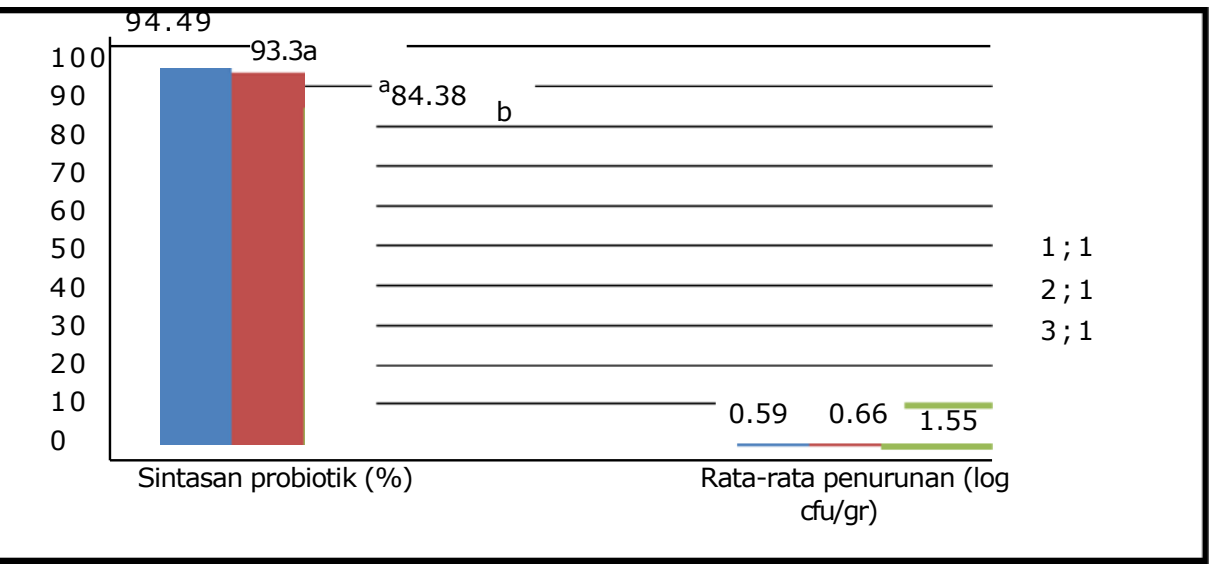

Gambar 1. Sintasan probiotik bio-kapsul setelah ekstrusi karagenan-skim

Dapat dilihat dari Gambar 1 bahwa sintasan probiotik bio-kapsul terenkapsulasi karagenan-skim perbandingan 1:1 dan 2:1 tidak berbeda nyata dan berbeda nyata dengan perbandinag $3: 1$ berturut turut $94,49 \%, 93.3 \%$, dan $84,38 \%$ dengan penurunan rata-rata 0,59 $\log$ CFU/gr pada perbandingan 1;1 dan $0.66 \log$ CFU/gr pada 2:1. Penurunan sintasan tertinggi pada perbandingan karagenan-skim 3;1 yaitu sebesar 1.55 log CFU/gr. Menurut Ding dan Shah (2009), karagenan adalah bahan enkapsulasi yang dapat melindungi sel bakteri dari pengaruh lingkungan dan tekanan. Ditambahkan oleh Solanki et al (2013), karagenan memiliki kemampuan untuk dapat memerangkap sel probiotik dengan baik dalam kondisi hangat pada suhu $40-45^{\circ} \mathrm{C}$.

\section{Viabilitas bio-kapsul}

Viabilitas sel Lactobacillus paracasei ssp paracesi M13 dengan berbagai perbandingan bahan penyalut karagenan-skim dapat dilihat pada Tabel 2.

Tabel 2. Viabilitas sel bebas dan sel (CFU/g) dalam bio-kapsul karagenan-skim pada berbagai perbandingan.

\begin{tabular}{cccc}
\hline $\begin{array}{l}\text { Perbandingan } \\
\begin{array}{l}\text { Penyalut } \\
\text { karagenan- } \\
\text { skim }\end{array}\end{array}$ & $\begin{array}{l}\text { Viabilitas Sel bebas } \\
\text { Lb paracasei ssp } \\
\text { paracasei Ml3 } \\
\text { (CFU/g) }\end{array}$ & $\begin{array}{l}\text { Viabilitas Lb paracase } \\
\text { ssp paracasei Ml3 dalam } \\
\text { bio-kapsul (CFU/g) }\end{array}$ & $\begin{array}{l}\text { Penurunan } \\
\text { viabilitas sel } \\
\text { karena ektrusi } \\
(\text { log CFU/g) }\end{array}$ \\
\hline $1: 1$ & $6.3 \times 10^{9}$ & $1.5 \times 10^{9}$ & $0.5^{\mathrm{a}}$ \\
$2: 1$ & $1.03 \times 10^{10}$ & $1.97 \times 10^{9}$ & $0.72^{\mathrm{a}}$ \\
$3: 1$ & $1.8 \times 10^{10}$ & $7.5 \times 10^{8}$ & $1.38^{\mathrm{b}}$ \\
\hline
\end{tabular}

Keterangan: rata-rata perlakuan yang diikuti oleh huruf kecil yang sama menunjukkan tidak adanya perbedaan yang nyata pada tingkat kepercayaan 5\% 


\section{I.UMIBUNG}

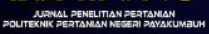

Pada perbandingan 1:1 tidak terjadi penurunan viabilitas sel sebelum dan sesudah enkapsulasi, tetapi penurunan terjadi pada perbandingan 2:1 dan 3:1. Penurunan viabilitas tertinggi terjadi pada perbandingan 3:1 yaitu sebesar 1.38 Log CFU/g. Bio-kapsul dengan diameter yang besar menyebabkan jumlah sel yang terjerap dalam kapsul menjadi lebih banyak dibandingkan dengan bio-kapsul dengan diameter yang lebih kecil.

Mortazavian et al. (2007), berpendapat bahwa bio-kpasul dengan ukuran diameter yang lebih besar dapat menyebabkan struktur menjadi lembek karena banyaknya air yang terjerap dalam sel, tetapi akan mampu menjerap sel mikroba dalam jumlah lebih banyak. Disamping itu ukuran diameter bio-kapsul yang besar memberikan penampakan yang kurang baik jika diaplikasikan pada poduk fementasi susu.

Menurut Krasaekoopt et al (2003), bahan enkapsulasi merupakan bahan pelindung yang berfungsi melindungi sel bakteri dari pengaruh eksternal sehingga proses memerangkap berlangsung sempurna.

\section{KESIMPULAN DAN SARAN}

Mikroenkapsulasi Lactobacillus paracasei ssp paracasei Ml3 dengan menggunakan teknik ekstrusi menggunakan bahan pelindung karagenan-susu skim pada berbagai perbandingan berpengaruh terhadap rendemen, sintasan probiotik dan viabilitas bio-kapsul setelah ekstrusi. Semakin tinggi perbandingan akan dihasilkan rendemen yang tinggi pula, tetapi berbanding terbalik dengan sintasan probiotik dan viabilitas sel setelah ekstrusi. Perbandingan karagenan - skim 2:1 menghasilkan viabilitas tertinggi setelah enkapsulasi sebesar $1.97 \times 10^{9} \mathrm{CFU} / \mathrm{gr}$, dengan penurunan sebesar 0,72 Log CFU/gr, rendemen $82.73 \%$ serta sintasan probiotik setelah enkapsulsai $93.3 \%$ atau mengalami penurunan rata-rata sebesar 0,66 Log CFU/gr.

\section{Saran}

Untuk tahap selanjutnya perlu dilakukan pengujian daya antimikroba dari bio-kapsul setelah enkapsulasi dan ketahanan terhadap $\mathrm{pH}$ rendah.

\section{REFERENSI}

Aneja, K.R. (2013). Experimen in microbiology, plant phatology and biotechnology. India : New Age International Publisher 


\section{I.UMIBUNG}

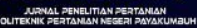

Bhadoria PBS, Mahapatra SC. 2011. Prospects, technological aspects and limitations of probiotics a worldwide review. European Jof Food Research \& Review 1(2): 23-42.

Desmond, C. C. Stanton, Collins, G.F.K., \& Ross, R.P. (2002). Improved survival of Lactobacillus paracasei NFBC 338 in spray dried powders containing gum acacia. J of Appl Microbiol 93:1003-1012.

Ding, W.K., dan N.P. Shah. 2009. Effect of various encapsulating materials on stability of Probiotik bacteria. Journal of Food Science 74:100-107.

Elida M, Gusmalini \& Izza A.S. (2018). Characteristics and viability of probiotics capsules Lactobacillus paracasei ssp paracasei M13 encapsulated by extrusion using carrageenan. ASIC International 2018.

Gebara C, Chaves KS, Ribeiro MCE, Souza FN, Grossp CRF, Gigante ML. 2013.. Viability of Lactobacillus acidophilusctin-whey protein microparticles during exposure to simulated gastrointestinal conditions. Food Res Int 51: 872-878. DOI: 10:1016/jfoodres 2013. 02.008.

Ivanovska, Tanja Petrusevska-Toji L., Kostoska M.K.D., Geskovski N., Grozdanov A., Stain C., Stafilov T., \& Mladenovska, K. (2012). Microencapsulation of Lactobacillus casei in chitosan-Ca-alginat microparticles usng spray dryng method. Maced J Chem Chem Eng 31: 115-123.

Krasaekoopt,W, , Bhandari. B, \& Deeth H. (2003). Evaluation of encapsulation techniques of probiotics for yoghurt. Int. Dairy J. 13:3-13. DOI: 10.1016/S09586946 (02)00155-3.

Le-Tien C, Millette M., Mateescu MA., Lacrox M. (2004). Modified algnate and chitosan for lactic acd bacteria immobilzation. Biotechnol Appl Biochem 39: 347 - 354.

Mortazavian, A., Razavi S.H., Ehsani M.R., Sohrabvandi S. (2007). Principle and methods of microcapsulation of probiotic microorganisms. Iranian J of Biotechnol $5: 1$-18.

Muhardian, V., Dewi,E., Yuliani A., \& Sri H. (2017). Pengaruh karagenan, alginat dan ampas tahu prebiotik terhadap visualisasi fisik dan rendemen kapsul probiotik. Seminar Nasional II USM 2017. Vol 1, Oktober 2017, 513-517

Rokka, S., \& Rantamaki P. (2010). Protecting probiotic bacteria by microencapsulation : challenges for industrial applications. Eur Food Technol . 231, 1-12.

Solanki, HK., D.K. Pawar., D.A. Shah., V.D. Prajapati., G.K. Jani., A.M. Mulla, dan P.M. Thakar. 2013. Development of Microencapsulation Delivery System for Long-Term Preservation of Probotics as Biotheraupetics Agent. Biomed Research Journal Vol. 2013.

Widodo, S., \& Wahyuni W. (2003). Biokapsulasi probiotik (Lactobacillus casei) dengan pollard dan tepung terigu serta pengaruhnya terhadap viabilitas dan laju pengasaman. J. teknol dan Industri Pangan. 14: 98-106 


\section{I.UMIBUNG}

Wu W, W.S. Roe, V.G. Gimino, V. Seriburi, D.E. Martin dan S.E. Knapp. 2000. Low melt encapsulation with high laurate canola oil. US. Patent 6153326.

Yunita, E. (2011). Karakteristik fisiko-kimia karagenan dan histologi rumput laut Kappaphycus alvarezii dari darah asal bibit dan umur panen berbeda. Thesis. Bogor. Sekolah Pascasarjana Institut Pertanian Bogor.

Zanjani MAK, tarzi BG, Sharifan A, Mohammad N. 2014. Microencapsulation of probiotics by calcium alginate-gelatinized starch with chitosan coating and evaqluation of survival in simulated human gastrointenstinal condition. Iran J Pharm Res 13: 843852. 